Article

\title{
Socially Inclusive Parenting Leaves and Parental Benefit Entitlements: Rethinking Care and Work Binaries
}

\author{
Andrea Doucet ${ }^{1,2}$ \\ ${ }^{1}$ Department of Sociology, Brock University, St. Catharines, ON L2S 3A1, Canada; E-Mail: adoucet@brocku.ca \\ ${ }^{2}$ Centre for Women's and Gender Studies, Faculty of Social Sciences, Brock University, St. Catharines, ON L2S 3A1, Canada
}

Submitted: 12 January 2021 | Accepted: 5 April 2021 | Published: 11 June 2021

\begin{abstract}
How can parental leave design be more socially inclusive? Should all parents be entitled to parental benefits or only those parents who are eligible based on a particular level of labour market participation? To think through questions of social inclusion in parental leave policy design, particularly issues related to entitlements to benefits, I make three arguments. First, aiming to extend Dobrotić and Blum's work on entitlements to parental benefits, I argue that 'mixed systems' that include both citizenship-based and employment-based benefits are just and socially inclusive approaches to parental leaves and citizenship. Second, to build a robust conceptual scaffolding for a 'mixed' benefits approach, I argue that that we need to attend to the histories and relationalities of the concepts and conceptual narratives that implicitly or explicitly inform parental leave policies and scholarship. Third, and more broadly, I argue that a metanarrative of care and work binaries underpins most scholarship and public and policy discourses on care work and paid work and on social policies, including parental leave policies. In this article, I outline revisioned conceptual narratives of care and work relationalities, arguing that they can begin to chip away at this metanarrative and that this kind of un-thinking and rethinking can help us to envision parental leave beyond employment policy-as care and work policy. Specifically, I focus on conceptual narratives that combine (1) care and work intra-connections, (2) ethics of care and justice, and (3) 'social care,' 'caring with,' transformative social protection, and social citizenship. Methodologically and epistemologically, this article is guided by my reading of Margaret Somers' genealogical and relational approach to concepts, conceptual narratives, and metanarratives, and it is written in a Global North socio-economic context marked by the COVID-19 pandemic and 21st century neoliberalism.
\end{abstract}

\section{Keywords}

care; care and justice; conceptual narratives; historical sociology of concept formation; parental leave; parenting leaves; social care; social citizenship; transformative social protection

\section{Issue}

This article is part of the issue "The Inclusiveness of Social Rights: The Case of Parental Leave Policies" edited by Sonja Blum (University of Hagen, Germany) and Ivana Dobrotić (University of Oxford, UK / University of Zagreb, Croatia).

(C) 2021 by the author; licensee Cogitatio (Lisbon, Portugal). This article is licensed under a Creative Commons Attribution 4.0 International License (CC BY).

\section{Introduction}

Since the beginning of the 21st century, advanced capitalism's "current, financialized phase," with its growing "care deficits" and "care crises" (Fraser, 2016, p. 100) have profoundly affected how parents care and provide for their families and children and how policies are designed to support those care and provisioning practices. These matters have become even more urgent since the COVID-19 pandemic, which has had a global impact on people's everyday care and work lives through repeated lockdowns, social distancing protocols, closures of childcare centers and schools, and workplace disruptions and reconfigurations. Prior to the pandemic, it was already clear that because of the rise of gig economies and precarious employment, more and more parents around the globe were not meeting the entitlements and eligibility criteria needed to receive employment-based parental leave benefits (Dobrotić \& Blum, 2019, 2020; McKay, Mathieu, \& Doucet, 2016; Moss \& Deven, 2015, 2019). The pandemic has thus deepened and extended processes of rethinking social 
policy design that were already beginning throughout the Global North, and this includes questions about how to make parental leave policies more inclusive and responsive to rising employment precarity.

One fruitful way to address how employment-based benefits exclude growing numbers of parents, and to design parental leaves that are more socially inclusive can be found in Ivana Dobrotić and Sonja Blum's $(2019,2020)$ conceptual framework. In their assessment of social inclusion and exclusion in parental leave design and parental benefits, they discuss three types of benefits: employment-based benefits, citizenship basedbenefits, and 'mixed benefits' systems. They also highlight three dimensions that need to be examined when analyzing parental benefits: (1) entitlement principles (e.g., citizenship vs. employment-based rights), (2) eligibility criteria (e.g., citizenship duration, employment history, means testing), and (3) benefit scope (e.g., benefit level/duration; see Dobrotić \& Blum, 2020, p. 592). Analytically, this tri-partite focus facilitates "capturing at the analytical level which kind and amount of support may be claimed under which conditions" (Blank, 2007, p. 8 , as cited in Dobrotić \& Blum, 2020, p. 592). These authors assess whether eligibility criteria are selective or universal and identify four ideal approaches to granting parental leave-related benefits (in)dependent of parents' labour market position (a universal parenthood model, a selective parenthood model, a universal adultworker model, and a selective adult-worker model). They also develop an eligibility index to measure the inclusiveness of parental-leave benefits, particularly the extent to which benefits are available to all parents.

Building on some of Dobrotić and Blum's significant contributions to parental leave design, my overarching question in this article is: How can parental leave design be more socially inclusive? My interest in social inclusion reveals an assumption that underpins this inquiry: that all infants should be entitled to receive care that has some financial support, regardless of whether and how their parents are employed in the formal labour market (or in ways that meet eligibility criteria for employmentbased benefits).

The question of inclusivity in parental leave design reflects a wider conceptual problem that dominates parental leave scholarship and design in many countries, including Canada (from where I am writing). This problem is that parental leave is viewed, conceptualized, and operationalized predominantly as employment policyas job-protected entitlements to leaves from paid work for care work, and as parental benefit payments to reimburse a portion of parents' labour market earnings while they take on that care work. The logics of legal entitlements to paid and unpaid leaves from employment varies vastly within and across countries and social welfare regimes, as does the issue of who pays for parental benefits (i.e., different levels of government, employers, individual contributions through taxes or employee deductions, or a combination of these). Yet, regard- less of how policies are administered, the position that parental benefits should be attached to employmentrather than based on citizenship - continues to dominate at an ideational level. As Dobrotić and Blum write (2020, p. 604), in some countries citizenship-based benefits are "less generous in their scope (typically low, flat-rate benefits) and alone are hardly able to incorporate care into citizens' life without endangering their autonomy, independence, and self-development." Meanwhile, even in countries with employment-based benefits, policy design can be guided by the ideal of the full-time standard, formal employment relationship; that is, there can be differences in how employees are treated, and those who do not fulfill the requirements for a particular number of months or insurable hours or who have switched or lost an employer in the months or year before giving birth will receive lower benefits or no benefits at all (for international examples see Dobrotić \& Blum, 2020; for a Canadian example see Mathieu, Doucet, \& McKay, 2020; Mckay et al., 2016).

Framing parental leave policy as mainly employment policy is not just about policy design and political will. It is also rooted in how we think about, speak about, and live within particular metanarratives-in this case a metanarrative of divisions between concepts and practices of care and work, and unpaid care work and paid work. Overall, I argue that most scholarship and public and policy discourses in the Global North on matters of care and work, including policy thinking on parental leave, is still informed by an enduring binary opposition of paid work - as an economic and productive activity-and unpaid care work-as a non-economic, non-productive activity outside of the formal economy. This metanarrative of paid work and unpaid care work binaries is perhaps most boldly apparent in how the GDP does not include unpaid work or unpaid care work in its measurement of economic productivity, prosperity, or wealth across the globe (e.g., Waring, 1988, 1999). It can also be seen in the widespread notion in public and policy discourses that the work people do to financially sustain their families is distinct and separate from the work they do to care for their families. It is further revealed in the systemic persistence of analytical categories such as stayat-home mother, stay-at-home father, working mother, and working father, which indicate an assumption that people are either working or caring, when most people are actually engaging in both work and caring at any one point in time as well as in varied ways across the life course (see also Doucet, 2016, 2020). I argue that to unthink and rethink parental leave benefits as more than employment and labour market policies, and as socially inclusive care/work policies, we need a care-focused conceptual scaffolding that acknowledges the intra-actions of care work and paid work, care and justice, and care and social citizenship.

The aim of this article is twofold. First, it aims to challenge a dominant metanarrative of binaries of care and work, unpaid care work and paid work. Guided by 
Margaret Somers' (1996, 2008, p. 209) historical sociology of concept formation, which is a "genealogical accounting of conceptual configurations," as well as her writing on narratives, conceptual narratives, and metanarratives (Somers, 1994, 1995), this aim means "taking a look" at the "relational patterns" (Somers, 2008, p. 204) of concepts and conceptual narratives, while always being cognizant that any inquiry is a temporal and geo-political "activity that is irrevocably linked to its current uses" (Dean, 1994, p. 14, as cited in Somers, 2008, p. 10). The overall goal of such an exercise is to gain a "sense of how we think and why we seem obliged to think in certain ways" (Hacking, 1990, p. 362) while also figuring out "how to begin the process of unthinking" (Somers, 2008, p. 267).

Second, guided by the view that metanarratives change as other intertwining narratives change, including the stories people tell ("ontological narratives"), "social, public and cultural narratives," and "conceptual narratives" (Somers, 1994, p. 616), this article aims to rethink the conceptual narratives that undergird a metanarrative of care and work separations and divisions. My focus here is on conceptual narratives, and, more specifically, on building conceptual narratives of care and work relationalities that support socially inclusive entitlements to parental benefits. I expand Dobrotić and Blum's conceptual frame, which is partly based on theories of social rights (e.g., Esping-Andersen, 1990; Marshall, 1964), and which attempts "to grasp the complex relationship between rights and obligations and... ongoing trends in social citizenship" (Dobrotić \& Blum, 2020, p. 592). I complement these conceptual pathways with selected insights from scholarly literatures on relationalities of care and work as well as insights from the ethic of care, social care, social protection, and social citizenship. I argue that together, these revisioned conceptual narratives begin to generate a new metanarrative of care and work, and unpaid care work and paid work as intra-connections, rather than as binaries. In the case of parental leave policies and parental benefits, this kind of un-thinking and rethinking can help us to envision parental leave beyond employment policy, as care/work policy.

This article is organized in two parts. First, I briefly outline my approach to concepts and conceptual narratives. Second, I lay out one mapping of the concept of care by focusing on selected parts of the histories of care and related networks of concepts: (1) care and work intra-connections, (2) the ethics of care and of justice, and (3) 'social care,' 'caring with,' care and social protection, and social citizenship.

I also mention four notes that frame this article. To capture the breadth of what I am advocating, I borrow from O'Brien and Moss (2020, p. 204), who recently used the "summary term 'parenting leave" " to "encompass the full range of statutory leave policies." Parenting leave enables a discussion of leave to care for infants and young children without getting into the details of the par- ticular policy measures defined by the terms 'maternity leave,' 'paternity leave,' and 'parental leave' and their differences within and between countries.

Furthermore, I do not engage with the specifics of eligibility criteria (citizenship duration, employment hours, or means testing) or with levels and durations of benefits. Drawing from Esping-Andersen (1990), I do, however, recognize that different welfare state models likely require different approaches to benefit entitlement criteria. For example, social democratic welfare states lean towards extending benefits based on citizenship, conservative welfare states tend to prioritize employment-based benefits, and in liberal welfare states, more emphasis is often placed on means-testing to determine eligibility for benefits (see Baird \& O'Brien, 2015; Dobrotić \& Blum, 2019).

A third note is about the concept of 'work,' which I use interchangeably with 'paid work' and 'employment' for ease and clarity in my writing. These and related concepts, such as provisioning (see Neysmith, Reitsma-Street, Baker-Collins, Porter, \& Tam, 2010) and breadwinning (see Warren, 2007), each have their own conceptual histories that extend beyond the scope of this article.

Finally, the epistemological and methodological terrain that I travel in this article is wide and deep and in the short space of this article I am only able to provide a brief glimpse of its complexities. I do not undertake a full genealogy of the concepts of care and work nor enact a full genealogical excavation of a metanarrative of care and work binaries. Rather, my goals are to begin to map new conceptual narratives of care and work that can support socially inclusive parental benefits as care and work policies, and to challenge and ultimately to "undermine, dislodge, and replace a... dominant ideational regime" and metanarrative (Somers \& Block, 2005, p. 265).

\section{Epistemological and Methodological Approach to Concepts, Conceptual Narratives, and Metanarratives}

Somers' genealogical approach to concepts is rooted in a wide array of intersecting theoretical resources, including the work of Michel Foucault, lan Hacking, and Immanuel Wallerstein. It is also informed by her own earlier writing on narrative (e.g., Somers, 1994), which explores multiple and intersecting narrative forms (for an overview see Doucet, 2018a, 2018b, 2021). For Somers (2008, p. 2), metanarratives are, briefly put, "ideational regimes" that set "the parameters for what counts as worthwhile arguments in social and political debates." They are difficult to dislodge or replace because they have an "ideational embeddedness" (Somers, 2008, p. 23) that makes them largely invisible and taken for granted. Somers identifies similarities between metanarratives and Thomas Kuhn's (1962/1970) paradigms, writing that Kuhn "showed that what science has considered as confirming evidence has been influenced by what our dominant paradigms allow us to see and, most especially, 
to care about" (Somers, 1998, p. 728, emphasis added). In a similar way, a metanarrative "not only provides the range of acceptable answers but has the gatekeeping power to define both the questions to be asked and the rules of procedure by which they can rationally be answered" (Somers, 2008, p. 265).

Like all metanarratives, the work/care binary is neither permanent nor universal, yet its ideational rootedness gives it the "capacity to 'embed' other ideas, events, institutions, and issues," revealing "the constraining power of ideas and the role this power plays in-or, perhaps more appropriately, against-social and political economic change" (Foster, 2016, pp. 7-8). This raises the question: How, then, does systemic change occur?

Somers' historical sociology of concept formation offers very complex explications of how to approach moving beyond existing metanarratives towards making or excavating other metanarratives. One pathway offered by Somers (1995, p. 243, emphasis added) is based on the recognition that "At the heart of every narrative is a problem-a crisis or flash point." I maintain that a 'flash point' of the metanarrative of work and care divisions stems from "care deficits" and "care crises" (Fraser, 2016, p. 100) that have been brewing since at least the beginning of the 21st century and that have deepened throughout the COVID-19 pandemic. To address this problem and to "begin the process of unthinking" this metanarrative, (Somers, 2008, p. 267), we need a method for approaching concepts as "words in their historical sites" (Somers, 2008, p. 287)-not as singular objects, but as part of a conceptual network or a "relational matrix" (Somers, 2008, p. 203). Somers' historical sociology of concept formation, which I employ briefly and selectively in this article, is composed of three dimensions: epistemic reflexivity, the relationality of concepts, and the historicity of concepts.

\subsection{Epistemic Reflexivity}

Somers' approach to epistemic reflexivity is partly rooted in Bourdieu and Wacquant's (1992, p. 41) writing, which describes epistemic reflexivity as a "constant questioning of the categories and techniques of sociological analysis and of the relationship to the world they presuppose." In a similar way, Somers $(2008$, p. 172) describes it as a process of "turning social science back on itself to examine often taken-for-granted conceptual tools of research" and of moving from questions of 'what' to questions of 'how', thus "radically shifting the context of discovery (at least initially) from the external world to the cognitive tools by which we analyze this world" (Somers, 2008, p. 265).

Although the dominant "Nietzschean/Foucauldian legacy or lineage" (Knauft, 2017, p. 1) of genealogical methodologies provides a foundation for her approach, Somers $(1998,2008)$ departs from its critical empiricism in several ways. She maintains "that the empirical and the normative are mutually interdependent" (Somers,
2008, p. xiii) and that the questions we pursue are partly "problem driven" (Somers, 1998, p. 772) in that they "are driven by [our] place and concerns in the world" (Somers, 2008, p. 9). She also argues that they are "inherently ontological" because they "contain a priori decisions about how we understand the social world to be constituted" (Somers, 1996, p. 71).

Somers' (2011, p. 28) epistemic reflexivity is also evident in her view that all our research practices are historically and relationally contextual and contingent and that we work with "temporary analytic frames constructed... by the problem the researcher sets out to explain." These temporary frames are built on the recognition that in any given research site at any given time, there are multiple conceptual possibilities. The conceptual narratives and temporary frames that I develop in this article are thus specifically connected to the problems I address: social exclusion in parental benefits when entitlement is based solely on employment criteria, and how parenting leaves are determined and designed in diverse national contexts with rising levels of employment precarity.

\subsection{The Relationality of Concepts}

Somers' (1998, p. 767) discussion of the "relational configurations" of concepts builds on Hacking's (1990, p. 24) insight that "concepts are 'words in their sites." She writes that "All social science concepts lack natures or essences; instead, they have histories, networks, and narratives" (Somers, 2008, p. 257). The focus should thus be on what concepts do, especially in relation to other concepts, rather than on what concepts are. Acknowledging and working with the relationality of concepts shifts what we are studying. A concept "is not an isolated object but has a relational identity" and the "subject of research should be the entire conceptual network or the relational site in which it is embedded" (Somers, 2008 , p. 268). In this article, I argue accordingly that care concepts, and what they are and what they do in any given site, can only be fully understood and applied from within their larger conceptual nets and their socioeconomic and geopolitical contexts, as well as in relation to the questions that guide a researcher's inquiry at any moment in time.

\subsection{The Historicity of Concepts}

Historical epistemologies are a set of philosophical and epistemological ideas about how "successful truth claims are historically contingent rather than confirmations of absolute and unchanging reality" (Somers, 2008, p. 257) and how "things we take as self-evident and necessary... simply take on the appearance of being the only possible reality" (Somers, 2008, p. 10). Somers argues that "understanding how concepts gain and lose their currency and legitimacy is the task of historical epistemology, which entails reconstructing their making, resonance, and connectedness over time" (Somers, 2008, 
p. 268). This means looking at the historicity of concepts and recognizing not only how they came into being, but what keeps them in place. There are always "other competing conceptual networks" (Somers, 2008, p. 206).

The concepts and conceptual narratives I employ in this article about care and work, care and justice, and care and social citizenship lead me to tell a particular scholarly narrative about the conceptual scaffolding that can support the idea of socially inclusive parental leave benefits. Attending to epistemic reflexivity and the relationality and historicity of concepts, I investigate the concept of care in several 'sites,' signaling an approach that is not only about care, but about care in varied conceptual configurations. Specifically, I explore three conceptual narratives that help to dissolve boundaries and enact relationalities, between care and work: (1) care and work intra-connections, (2) the ethics of care and justice, and (3) care, social protection, and social citizenship.

\section{Care and Work Intra-Connections}

Mapping a new metanarrative of care and work requires "taking a look" at the "relational patterns" (Somers, 2008, p. 204) of the varied intersections between concepts of care and work, which have taken on varied guises throughout history. As genealogical work does not seek origins but, rather, relational conditions of possibility, I am not looking for a particular beginning of the dominant metanarrative of care and work binaries, although there are historical moments that indicate its increasing sedimentation. Nancy Folbre (1991, p. 464) highlights one such historical moment when she notes that while in population censuses from the 19th century, mothers and wives were "considered productive workers," this view shifted in the early 20th century, when women were "formally relegated to the category of 'dependents,' a category that included infants, young children, the sick, and the elderly." The 'unproductive housewife' and 'productive male breadwinner' concepts were constituted within a metanarrative of care and work divisions that they also helped to strengthen.

Since the mid 20th century, feminist scholars and activists have sought to both recognize and value women's unpaid work, including housework and the care of children, and have challenged a metanarrative of care and work binaries through at least five unfolding conceptual counternarratives of care and work relationalities. The first is the view that care work is indeed 'work' -an idea that gained traction on scholarly and activist agendas in the 1960s and 1970s. This perspective was instigated mainly by feminist scholars researching mothering and the meanings and practices of women's daily caregiving and domestic tasks, both as forms of work and as subjects worthy of scholarly attention (e.g., Oakley, 1974/2018).

A second conceptual narrative relates to the inseparability of care and work as everyday practices. This can be seen in early sociological work that asserts that "car- ing demands both love and labour, both identity and activity" (Graham, 1983, pp. 13-14). The inseparability of care and work is also apparent in research that entangles the concepts of care and provisioning, where the latter is defined as all work "whether paid or unpaid in the market, home, or community spheres" that is "performed to acquire material and intangible resources for meeting responsibilities that ensure the survival and well-being of people" (Neysmith et al., 2010, p. 152). This concept of provisioning emerged mainly from the research of feminist economists, who, in studying multiple forms of women's unpaid care work and paid employment in the Global North and South, sought to avoid being "impeded by conceptual barriers of public and private spheres that interrupt and thus hide the extent of the work" (Neysmith et al., 2010, p. 164). It also resonates with scholarship on mothering outside of middle class, white, and Euro-western cultures. As Hill Collins (1994, p. 372) argued nearly thirty years ago, "examining racial ethnic women's experiences reveals how these two spheres" of paid work and family are not only connected, but "actually are interwoven" (see also Dow, 2019).

A third point about intra-connections between care and work is the widely recognized idea that all societies and economies rely on and are only made possible by care labor. Initial versions of the feminist concept of social reproduction, a sister to the concept of care, made this point especially well as they attempted to integrate women's domestic labor into broader Marxist analyses of production and capitalist relations (e.g., Molyneux, 1979). Feminist economics and ongoing work on social reproduction have continued to underline the strong intra-connections between concepts and practices of care work and economies, care work and paid work (e.g., Bezanson \& Luxton, 2006; Fraser, 2016; Himmelweit, 2007). This is encapsulated in what Folbre (1994a, p. 16) called the "free rider" problem, where those "who devote relatively little time or energy to childrearing are free-riding on parental labor." As she puts it, while children are "public goods" (Folbre, 1994b, p. 86) whose proper care leads them to become productive adults who then contribute to the maintenance of strong economies, the overwhelming costs of this care are, nevertheless, borne by few-mainly women (see also Fraser, 2016; Tronto, 2013).

My fourth point about emerging conceptual narratives of care/work intra-connections is one that has deepened in recent years, owing in part to a growing field of research on care economies and to conceptual insights about an "unpaid care work-paid work-paid care work circle" (Addati et al., 2018, p. 10, emphasis added). Recognizing these interconnections is certainly not new (i.e., Duffy, Albelda, \& Hammonds, 2014; Thomas, 1993), but the second decade of the 21st century and the COVID-19 pandemic have brought more attention to how unpaid care work supports paid work and to how paid care work is an intricate part of economic growth, gender and class equity, and social inclusion. Recent studies, for 
example, have highlighted how investing in care workers and the physical infrastructure to support paid care work has multiple economic and GDP-connected benefits (e.g., De Henau \& Himmelweit, 2020).

Finally, linking this care circle and care-work intraconnections to parenting leaves could lead to policy approaches that focus on the relationalities of care and work both for parents who are employed in the standard employment relationship and those who are not. This approach acknowledges that "for inactive or unemployed parents, parental leave benefits also include time off from actively looking for a job to focus on care" (Dobrotić \& Blum, 2020, p. 589), while for employed parents, "paid parental leave gives not only the right to take time off from work to focus on care but also the duty, since parents are typically not allowed to work (full time) while on leave" (Dobrotić \& Blum, 2020, p. 589). Put differently, when a new child enters the world, parents need job-protected paid leaves from employment or, if they are between jobs or not engaged in paid work, parents need respite from having to secure paid work in order to take on the socially valuable work of caring for their child.

This conceptual narrative of care and work intraconnections can be buttressed by a wider look at other related conceptual narratives, including one that seeks to entangle the ethics of care and justice.

\section{Ethics of Care and Ethics of Justice}

One mapping of the multiple histories of the concept of care and the ethic of care begins in the late 1970s, with Carol Gilligan's (1982/1993; see also Gilligan, 1977) In a Different Voice, which has been called "one of most influential books of the 1980s" because it "revolutionized discussion of moral theory, feminism [and] theories of the subject" (Hekman, 1995, p. 1). Along with other well-known and related works (e.g., Ruddick, 1995; Sevenhuijsen, 1998), Gilligan's book led to a massive cross-disciplinary field already characterized by the 1990 s as "a small industry within academia and outside the academy" (Jaggar, 1991, p. 83). Since then, the field of care theories and care ethics has deepened and widened in response to changing historical, socioeconomic, and political contexts. Yet two of its early interventions remain central to the field of care, and I draw on them here.

A first, lasting tenet from the ethic of care is the view that human subjectivities, or selves, are relational and interdependent. This assertion was initially meant to challenge and provide alternatives to dominant conceptions of human subjectivity that emphasized individuality, independence, autonomy, and rationality, which were part of liberal political and economic theory, highly influential work on moral and human development (e.g., Kohlberg, 1981), and theories of justice (e.g., Rawls, 1971). Discussions about the relationality and individuality of selves have offered contrasting and compet- ing perspectives at varied points in the development of care theories. Taking a view of concepts as "words in their sites" means that particular contextual sites and problematics will lead to multiple ways of approaching human subjectivities.

For the problematic I take up in this article, relational and independent selves are both critical. A focus on relational selves recognizes that all people are dependent on the care of others at varied points in our lives-when we are very young, very old, during illness, and at many other times across the life course. Yet, people's independence and autonomy can also be viewed as important aspects of their subjectivity. That is, parenting is about both caregiving and provisioning for that care, and thus it involves combinations of relational and autonomous subjectivities in both care work and paid work activities (see Doucet, 2016, 2020). This perspective embraces fluid, shifting, and varied degrees of dependence, independence, and interdependence as well as varied versions of 'relational autonomy' (Friedman, 2014). It can also inform a reconceptualization of parental benefits as both care and work policies that support people's family identities and practices as simultaneously relational and autonomous, while also recognizing that early parenthood is a unique temporal site where relationality and interdependence is heightened for parents as well as for infants.

A second and related central argument from the ethic of care field concerns the relationship between the ethic of care and the ethic of justice. Whereas, put briefly, the ethic of care focuses on responsiveness and attentiveness (Ruddick, 1995; Tronto, 1993, 2013), the ethic of justice focuses on issues of equality, fairness, and individual rights (for an overview see Gilligan, 1982/1993; Held, 2006). Most care theorists follow Gilligan (1982/1993, 1986), who was clear that the ethics of both care and justice are important and indeed complementary (Tronto, 1993; see also Noddings, 1984). Yet despite long conversations about their possible interconnectedness, "how this complementarity should be articulated remains a terrain for debate" (Casalini, 2020, p. 59). As Virginia Held (2006, p. 66) writes: "How does the framework that structures justice, equality, rights, and liberty mesh with the network that delineates care, relatedness, and trust?"

My argument here is that the ethic of care and the ethic of justice are both important in families and in state and employment policies. Broadly speaking, they are critical for equitable gendered divisions of household labour and care and for fair wages to support caregivers working in care services (both childcare and eldercare). One articulation of the intersection between the ethics of care and of justice can be found in socially inclusive parental leave design, where attention is given both to relational conceptions of subjectivity as well as to intra-connections between care and justice. The work of feminist legal scholar Martha Fineman (2010, p. 267) is useful here as she combines care and justice concerns 
while also widening the idea of relational subjectivities to argue that "human vulnerability must be at the heart of our ideas of social and state responsibility." Although Fineman does not explicitly refer to the issue of parental benefits, her theoretical insights are useful for thinking through the limitations of employment-based parental benefits and how the work of caring for vulnerable others, such as infants, requires social and financial support. As she puts it: "Those who care... through essential caretaking work are themselves dependent on resources in order to undertake that care, and these resources must be supplied by society through its institutions" (Fineman, 2009, p. 445).

\section{5. 'Social Care,' 'Caring With,' Transformative Social Protection, and Social Citizenship}

In my conceptual mapping, conceptual narratives of care and justice, which include relational and interdependent conceptions of subjectivity, lead to other neighboring concepts, such as 'social care,' 'caring with,' transformative social protection, and social citizenship; these are all linked to how care is embedded (or not) in social welfare state policies. 'Social care' was developed with "the aim of clarifying and developing its analytic potential in relation to the study of welfare states and how they are changing" (Daly \& Lewis, 2000, p. 281). Since the 1990s, there have been arguments about the need to widen the concept of care beyond its earlier focus on care and gendered work in the home (e.g., Tronto, 1993; Sevenhuijsen, 1998). Building on this, Daly and Lewis (2000, p. 285) have argued that in welfare state analysis, the concept of care should be reconceptualized to respond to the specificities of people's care lives as well as "the societal arrangements around personal needs and welfare." Their arguments, first made in 2000, remain salient today because they highlight welfare state "retrenchment" and "cut-backs" in the "state as provider (of cash and care)" (Daly \& Lewis, 2000, p. 282), where cash could include, for example, parental benefits, and services could include childcare and early learning services. Rather than delegate the delivery of these benefits and services to families and the voluntary sector and to resist the move towards a stronger role for markets "either directly as a provider or indirectly as a purveyor of particular principles," Daly and Lewis (2000, p. 282) call for a stronger role for the state.

The concept of social care, which reconceptualizes "care in such a way as to capture the social and political economy within which it is embedded," underlines how responding to people's care needs and their financial responsibilities to support that care should be at "the very center of welfare state activity" (Daly \& Lewis, 2000, p. 282). Such an approach, where care is relatively central in state policies, is being used in some countries. As Dobrotić and Blum (2020, p. 608) point out, "it seems quite likely that the (EU-promoted) social investment perspective and the 'Nordic model' advocated in family policies could serve as such exemplary models" of convergence between employment-based and citizenshipbased benefits; these are "mixed models that try to equally balance the inclusiveness of both leave entitlement types" (Dobrotić \& Blum, 2020, p. 603). On the other hand, they note that in spite of expansions in parental leave policies, for the 21 European countries in their study, "not much effort is made to install benefits, which are more inclusive to those inactive in the labor market or across different employment forms and sectors" (Dobrotić \& Blum, 2020, p. 607).

The social care dimension of this conceptual narrative also connects to Joan Tronto's $(1993,2013)$ decades of writing on the ethics of care and "processes of care" and, more recently, on "processes of democratic caring" (Tronto, 2013, p. 22). These processes include four stages of care: caring about someone's unmet needs, caring for those needs, caregiving and making sure the work is done, and care-receiving or assessing the effectiveness of those care acts (Tronto, 2013). Tronto later broadened these care processes to include a fifth stage that weaves together the ethics of care and justice-'caring with'-which "requires that caring needs and the ways in which they are met need to be consistent with democratic commitments to justice, equality, and freedom for all" (Tronto, 2013, p. 23). All five stages of care practices are "nested within one another" and aim "to ensure that all of the members of the society can live as well as possible by making the society as democratic as possible" (Tronto, 2013, p. 40). Tronto's version of democratic caring positions all citizens (including infants) as equal in their roles as care receivers. In relation to parenting leaves and parental benefits, 'caring with,' like 'social care,' puts care, care giving, and care receiving at the center of social policy and positions it "as a central value for democracies" (Tronto, 2013, p. 29). On my reading, this endorses a mixed system of parental benefits that can provide some state support for all five stages of care.

If we widen this conceptual network of care and work relationalities, the concepts of social care and 'caring with' can connect to a 'transformative social protection approach' (e.g., Devereux, Roelen, \& Ulrichs, 2015; ILO, 2014; Sabates-Wheeler \& Devereux, 2007). This approach, arising from research from the Global South and North on issues of care, poverty reduction, social well-being, and rights-based dimensions, supports a shift from a narrower scope of economic protection (such as unemployment insurance) to a broader view of social protections. It is also founded on "an appreciation of structural inequalities" and attempts to address them through "a political approach to social protection, focusing on rights, duties, democracy and advocacy" (Sabates-Wheeler \& Devereux, 2007, p. 1). A transformative approach to social protection has its own conceptual histories and relationalities, and this includes connections to rights-based approaches to citizenship (e.g., Kabeer, 2002). As stated by the United Nations Research Institute for Social Development (UNRISD, 2016, p. 102): 
"A rights-based approach to care recognizes both caregivers and care receivers as rights-holders, and positions the state as a duty-bearer." A care and social protection approach can, in turn, "help realize the rights of caregivers and care receivers, and therefore contribute to multiple dimensions of equality, and at the same time can have positive macroeconomic effects" (UNRISD, 2016, p. 222). With regard to parenting leaves, a transformative social protection approach that combines care and work, care and justice, and conceptions of relational and relationally autonomous subjectivities, provides conceptual space to make a case for every child's right-as a care receiver - to good care, for parents' social rights to provide good care, and for the state to support these care-receiving and caregiving rights (see Doucet, McKay, \& Mathieu, 2019; Haas \& Hwang, 1999; Moss \& Deven, 2015, 2019).

One remaining task in creating this conceptual configuration is to connect care with the neighboring concepts of transformative social protection and social citizenship. In Somers' work across several decades (e.g., Block \& Somers, 2014; Somers, 2008; Somers \& Block, 2005), she demarcates a highly complex "cluster of rights at the heart of democratic and socially inclusive citizenship regimes" and argues that these rights must be "recognized to be public goods" (Somers, 2008, p. 5). One of these social rights is the "right to political membership," including "the de facto right to social inclusion in civil society" (Somers, 2008, p. 6). Yet, it is also clear for Somers (2008, p. 117) that "in today's culture of market fundamentalism," markets can be "fundamentally threatening to human freedom and the collective good." She thus maintains, with Block, that some dimensions of social life, including caregiving and care receiving, "have to be protected from the market by social and political institutions and recognized as rights rather than commodities, or human freedom will be endangered" (Block \& Somers, 2014, p. 8).

In relation to parenting leave and parental benefits (and other social benefits), feminists have long argued that receiving benefits on the basis of citizenship can help address social inequalities of gender, race, ethnicity, age, sexuality, and ability/disability. (e.g., Orloff, 1993). This is especially important now, with the current "juggernaut of neoliberalism" (Moss, 2014, p. 6), rising rates of immigration, racialized inequalities, and the longoverdue, urgent need for societies to address the social and political exclusion and marginalization of Indigenous populations (e.g., Benhabib, 2004; Jewell, Doucet, Falk, \& Fyke, 2020; Tuck \& Yang, 2012). As Somers and Curtis (2016, p. 15, emphasis added) express it:

Citizenship rights and full social inclusion, while always subject to the violence and violations of racial and gender exclusions, have now more than ever been converted from rights into a set of contingent privileges, ultimately dependent on one's economic means and market exchange value.

\section{Conclusion}

In this article, I explored the question of how parental leave design can be more socially inclusive and responsive to rising employment precarity, neoliberalism, and more recent pandemic and post-pandemic socioeconomic worlds. I did so by building on selected parts of Dobrotić and Blum's $(2019,2020)$ conceptual and comparative work on entitlements to parental benefits and their view that a "mixed system that combines both logics in policy design" (i.e., both employment-based and citizenship-based parental leave benefits) "can be considered... an inclusive design of parental-leave benefits" (Dobrotić \& Blum, 2020, p. 597). More broadly, I approached this problematic through the wider argument that most scholarship and public and policy discourses in the Global North on care and work, including policy thinking on parenting leaves, is underpinned by a binary opposition of paid work-as an economic and productive activity-and unpaid care work-as a non-economic, non-productive activity outside of the formal economy. I further argued that in order to think through inclusive parenting leave policies, we need to unthink and rethink this metanarrative of care and work binaries.

Chipping away at this metanarrative while working towards one that holds relationalities of care and work, my reading of Somers' historical sociology of concept formation guided me to engage in a brief genealogical exercise. I attended to selected histories and relationalities of care and neighboring concepts, focusing mainly on considering the possibilities for revisioned conceptual narratives. I articulated parts of three conceptual narrative pillars-(1) care and work intra-connections, (2) the ethics of care and justice, and (3) 'social care,' 'caring with,' transformative social protection, and social citizenship-that could provide the scaffolding for more socially inclusive and just parenting leave policies.

The arguments made in this article call for wider thinking about parenting leaves, care, and work. In the face of growing informal and non-standard employment-issues that have only deepened through the COVID-19 pandemic-benefits allocated for parenting leaves (including parental leave, maternity leave, and paternity leave) clearly need to be disentangled, at least partially, from the labour market. Reconfiguring parenting leaves and entitlements to parental benefits will mean approaching them as both work and care policies, as matters of care and justice, as articulations of 'caring with' and 'social care,' as a complex set of social citizenship rights, and informed by a view of human subjectivity as both interdependent and relationally autonomous. Unthinking and rethinking a metanarrative of work and care binaries can create conceptual and political pathways that support entitlements to parental benefits that are conceptualized both as benefits to care as well as leaves from paid work to take on socially valuable care work. 


\section{Acknowledgments}

Many thanks to Sonja Blum, Ivana Dobrotić, Sophie Mathieu, Lindsey McKay, and two anonymous referees for comments; to Elizabeth Paradis for both comments and editing assistance, and to Kate Paterson for bibliographic assistance. This work was supported by the Social Sciences and Humanities Council of Canada (SSHRC) and its Canada Research Chairs program (file number 231901-2018) as well as the SSHRC Partnership Grant program (file number 895-2020-1011).

\section{Conflict of Interests}

The author declares no conflict of interests.

\section{References}

Addati, L., Cattaneo, U., Esquivel, V., \& Valarino, I. (2018). Care work and care jobs for the future of decent work. Geneva: International Labour Organization. Retrieved from https://www.ilo.org/global/ publications/books/WCMS_633135/lang--en/ index.htm

Baird, M., \& O'Brien, M. (2015). Dynamics of parental leave in Anglophone countries: The paradox of state expansion in liberal welfare regimes. Community, Work \& Family, 18(2), 198-217.

Benhabib, S. (2004). The rights of others. Cambridge: Cambridge University Press.

Bezanson, K., \& Luxton, M. (Eds.). (2006). Social reproduction: Feminist political economy challenges neoliberalism. Montreal and Kingston: McGill-Queen's University Press.

Block, F., \& Somers, M. (2014). The power of market fundamentalism: Karl Polanyi's critique. Cambridge, MA: Harvard University Press.

Bourdieu, P., \& Wacquant, L. J. D. (1992). An invitation to reflexive sociology. Chicago, IL: University of Chicago Press.

Casalini, B. (2020). Care and injustice. International Journal of Care and Caring, 4(1), 59-73. https://doi.org/ 10.1332/239788219X15730452949174

Daly, M., \& Lewis, J. (2000). The concept of social care and the analysis of contemporary welfare states. British Journal of Sociology, 51(2), 281-298.

De Henau, J., \& Himmelweit, S. (2020). A care-led recovery from coronavirus: The case for investment in care as a better post-pandemic economic stimulus than investment in construction. London: Women's Budget Group. Retrieved from https://wbg.org. uk/wp-content/uploads/2020/06/Care-led-recoveryfinal.pdf

Devereux, S., Roelen, K., \& Ulrichs, M. (2016). Where next for social protection? Institute of Development Studies, 47(4), 103-118.

Dobrotić, I., \& Blum, S. (2019). A social right: Access to leave and its relation to parents' labour market position. In P. Moss, A.-Z. Duvander, \& A. Koslowski (Eds.), Parental leave and beyond: Recent international developments, current issues and future directions (pp. 261-282). Bristol: Policy Press.

Dobrotić, I., \& Blum, S. (2020). Inclusiveness of parentalleave benefits in twenty-one European countries: Measuring social and gender inequalities in leave eligibility. Social Politics: International Studies in Gender, State \& Society, 27(3), 588-614.

Doucet, A. (2016). "The choice was made for us": Stay-athome dads (SAHDs) and relationalities of work and care. In I. Crespi \& E. Ruspini (Eds.), Balancing work and family in a changing society: The father's perspective (pp. 33-45). London: Palgrave Macmillan.

Doucet, A. (2018a). Do men mother? Fathering, care, parental responsibilities (2nd ed.). Toronto: University of Toronto Press.

Doucet, A. (2018b). Revisiting and remaking the listening guide: An ecological and ontological narrativity approach to analyzing fathering narratives. In A. Humble \& E. Radina (Eds.), How qualitative data analysis happens: Moving behind 'themes emerged' (pp. 80-94). Abingdon: Taylor and Francis.

Doucet, A. (2020). Father involvement, care, and breadwinning: Genealogies of concepts and revisioned conceptual narratives. Genealogy, 4(1), 1-17. https:// doi:10.3390/genealogy4010014

Doucet, A. (2021). A murex, an angel wing, the wider shore: An ecological and politico-ethico-ontoepistemological approach to narratives, stories, and testimonies. In N. A. McHugh \& A. Doucet (Eds.), Thinking responsibly, thinking ecologically: The legacies of Lorraine Code (pp. 95-147). New York, NY: State University of New York Press.

Doucet, A., McKay, L., \& Mathieu, S. (2019). Reimagining parental leave: A conceptual 'thought experiment.' In P. Moss, A.-Z. Duvander, \& A. Koslowski (Eds.), Parental leave and beyond: Recent developments, current issues, future directions (pp. 333-352). Bristol: Policy Press.

Dow, D. M. (2019). Mothering while black: Boundaries and burdens of middle-class parenthood. Berkeley, CA: University of California Press.

Duffy, M., Albelda, R., \& Hammonds, C. (2014). Counting care work: The empirical and policy applications of care theory. Social Problems, 60(2), 145-167.

Esping-Andersen, G. (1990). The three worlds of welfare capitalism. Princeton, NJ: Princeton University Press.

Fineman, M. A. (2009). Evolving images of gender and equality: A feminist journey. New England Law Review, 43(3), 435-458.

Fineman, M. A. (2010). The vulnerable subject and the responsive state. Emory Law Journal, 60, 251-275.

Folbre, N. (1991). The unproductive housewife: Her evolution in nineteenth century thought. Signs, 16(3), 463-484.

Folbre, N. (1994a). Who pays for the kids? Gender and the structures of constraint. London: Routledge. 
Folbre, N. (1994b). Children as public goods. The American Economic Review, 84(2), 86-90.

Foster, K. (2016). Productivity and prosperity: A historical sociology of productivist thought. Toronto: University of Toronto Press.

Fraser, N. (2016). Contradictions of capital and care. New Left Review, 100, 99-117.

Friedman, M. (2014). Relational autonomy and independence. In A. Veltman \& M. Piper (Eds.), Autonomy, oppression, and gender (pp. 42-60). Oxford: Oxford University Press.

Gilligan, C. (1977). In a different voice: Women's conceptions of self and of morality. Harvard Educational Review, 47(4), 481-517. https://doi.org/10.17763/ haer.47.4.g6167429416hg5I0

Gilligan, C. (1986). Reply by Carol Gilligan. Signs: Journal of Women in Culture and Society, 11(2), 324-333.

Gilligan, C. (1993). In a different voice: Psychological theory and women's development (2nd ed.). Cambridge, MA: Harvard University Press. (Original work published 1982)

Haas, L., \& Hwang, C. P. (1999). Parental leave in Sweden. In P. Moss \& F. Deven (Eds.), Parental leave: Progress or pitfall? Research and policy issues in Europe (Vol. 25, pp. 45-68). The Hague and Brussels: NIDI/CGBS Publications.

Graham, H. (1983). Caring: A labour of love. In J. Finch \& D. Groves (Eds.), A labour of love: Women, work and caring (pp. 13-30). London: Routledge.

Hacking, I. (1990). Two kinds of 'new historicism' for philosophers. New Literary History, 21, 343-364.

Hekman, S. (1995). Moral voices, moral selves: Carol Gilligan and feminist moral theory. Bristol: Polity Press.

Held, V. (2006). The ethics of care: Personal, political, and global. Oxford: Oxford University Press.

Hill Collins, P. (1994). Shifting the centre: Race, class, and feminist theorizing and motherhood. In D. Bassin (Ed.), Representations of motherhood (pp. 56-74). New Haven, CT: Yale University Press.

Himmelweit, S. (2007). The prospects for caring: Economic theory and policy analysis. Cambridge Journal of Economics, 31(4), 581-599. https://doi.org/ 10.1093/cje/bem011

ILO. (2014). World social protection report 2014/15: Building economic recovery, inclusive development and social justice. Geneva: International Labour Organization.

Jaggar, A. (1991). Feminist ethics: Projects, problems, prospects. In C. Card (Ed.), Feminist ethics (pp. 78-104). Lawrence, KS: University of Kansas Press.

Jewell, E., Doucet, A., Falk, J., \& Fyke, S. (2020). Social knowing, mental health, and the importance of Indigenous resources: A case study of Indigenous employment engagement in southwestern Ontario. Canadian Review of Social Policy, 80, 1-25.

Kabeer, N. (2002). Citizenship, affiliation and exclusion: Perspectives from the South. IDS Bulletin, 37(4), 91-101.
Knauft, B. (2017). What is genealogy? An anthropological/philosophical reconsideration. Genealogy, 1(1). https://doi.org/10.3390/genealogy1010005

Kohlberg, L. (1981). The philosophy of moral development. San Francisco, CA: Harper and Row.

Kuhn, T. (1970). The structure of scientific revolutions (2nd ed.). Chicago, IL: University of Chicago Press. (Original work published 1962)

Marshall, T. H. (1964). Citizenship and social class. In T. H. Marshall (Ed.), Class, citizenship and social development: Essays (pp. 65-122). Garden City, NY: Doubleday.

Mathieu, S., Doucet, A., \& McKay, L. (2020). Parental leave benefits and inter-provincial differences: The case of four Canadian provinces. Canadian Journal of Sociology, 45(2), 169-194. https://doi.org/ $10.29173 /$ cjs29504

McKay, L., Mathieu, S., \& Doucet, A. (2016). Parentalleave rich and parental-leave poor: Inequality in Canadian labour market based leave policies. Journal of Industrial Relations, 58(4), 543-562. https://doi: 10.1177/0022185616643558

Molyneux, M. (1979). Beyond the domestic labour debate. New Left Review, 116, 3-27.

Moss, P. (2014). Transformative change and real utopias in early childhood education: A story of democracy, experimentation and potentiality. London: Routledge.

Moss, P., \& Deven, F. (2015). Leave policies in challenging times: Reviewing the decade 2004-2014. Community, Work \& Family, 18(2), 137-144.

Moss, P., \& Deven, F. (2019). Leave policies in Europe: Current policies, future directions. International Journal of Sociology and Social Policy, 40(5/6), 429-440.

Neysmith, S. M., Reitsma-Street, M., Baker-Collins, S., Porter, E., \& Tam, S. (2010). Provisioning responsibilities: How relationships shape the work that women do. Canadian Review of Sociology, 47, 149-170.

Noddings, N. (1984). Caring, a feminine approach to ethics \& moral education. Berkeley, CA: University of California Press.

O'Brien, M., \& Moss, P. (2020). Towards an ECEC system in synergy with parenting leave. In C. Cameron \& P. Moss (Eds.), Transforming early childhood in England: Towards a democratic education (pp. 203-219). London: UCL Press.

Oakley, A. (2018). The sociology of housework (2nd ed.). Bristol: Policy Press. (Original work published 1974)

Orloff, A. S. (1993). Gender and the social rights of citizenship: The comparative analysis of gender relations and welfare states. American Sociological Review, 58(3), 303-328.

Rawls, J. (1971). A theory of justice. Cambridge, MA: Harvard University Press.

Ruddick, S. (1995). Maternal thinking: Towards a politics of peace (2nd ed.). Boston, MA: Beacon.

Sabates-Wheeler, R., \& Devereux, S. (2007). Social protection for transformation. IDS Bulletin, 38(3), 23-28. 
Sevenhuijsen, S. (1998). Citizenship and the ethics of care: Feminist considerations on justice, morality and politics. London: Routledge.

Somers, M. R. (1994). The narrative constitution of identity: A relational and network approach. Theory and Society, 23(5), 605-649.

Somers, M. R. (1995). What's political or cultural about political culture and the public sphere? Toward an historical sociology of concept formation. Sociological Theory, 13(2), 113-144.

Somers, M. R. (1996). Where is sociology after the historic turn? Knowledge cultures, narrativity and historical epistemologies. In T. J. McDonald (Ed.), The historic turn in the human sciences (pp. 53-89). Ann Arbor, MI: University of Michigan Press.

Somers, M. R. (1998). "We're no angels": Rational choice, and relationality in social science. Journal of Sociology, 104(3), 722-784.

Somers, M. R. (2008). Genealogies of citizenship: Markets, statelessness and the right to have rights. Cambridge: Cambridge University Press.

Somers, M. (2011). Reply to the critics: Book symposium-Genealogies of citizenship: Markets, statelessness, and the right to have rights. Trajectories, 22(2), 25-33.

Somers, M., \& Block, F. (2005). From poverty to perversity: Ideas, markets, and institutions over 200 years of welfare debate. American Sociological Review,
70(2), 260-287.

Somers, M., \& Curtis, J. (2016). Socially embedding the market and the role of law: An interview with Margaret Somers. London: The Laboratory for Advanced Research on the Global Economy, Centre for the Study of Human Rights, LSE.

Thomas, C. (1993). De-constructing concepts of care. Sociology, 27(4), 649-669.

Tronto, J. (1993). Moral boundaries: A political argument for an ethic of care. London: Routledge.

Tronto, J. (2013). Caring democracy: Markets, equality, and justice. New York, NY: New York University Press.

Tuck, E., \& Yang, K. W. (2012). Decolonization is not a metaphor. Decolonization: Indigeneity, Education \& Society, 1(1), 1-40.

United Nations Research Institute for Social Development. (2016). Policy innovations for transformative change: Implementing the 2030 agenda for sustainable development. Geneva: UNRISD.

Waring, M. (1988). If women counted: A New feminist economics. San Francisco, CA: Harper and Row.

Waring, M. (1999). Counting for nothing: What men value and what women are worth ( $2 \mathrm{nd}$ ed.). Toronto: University of Toronto Press.

Warren, T. (2007). Conceptualizing breadwinning work. Work, Employment \& Society, 21(2), 317-336. https://doi.org/10.1177/0950017007076642

\section{About the Author}

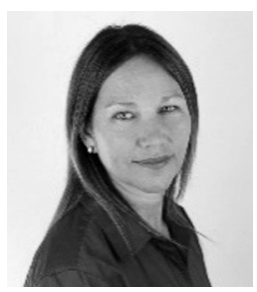

Andrea Doucet is a Canada Research Chair in Gender, Work, and Care, Professor in the Department of Sociology and Centre for Gender and Women's Studies at Brock University, and Adjunct Research Professor at Carleton University and the University of Victoria. She has published widely on parental leave, fathering, feminist and ecological epistemologies, narrative analysis, research ethics, care, and genealogies of concepts. She is Project Director and Principal Investigator of the "Reimagining Care/Work Policies" SSHRC Partnership grant project (2020-2028) and, as of September 2021, she will be Co-Coordinator of the International Network of Leave Policies and Research (2021-2026). 